\title{
II. SOILS FROM CULTIVATED STANDS OF SHOREA JAVANICA
}

\author{
M.J. SHEEHY SKHFFINGTON* \\ Tropical Forest Biology Program, BIOTROP, Bogor, Indonesia
}

Keywords: Soils, Shorea javanica, Sumatra

\begin{abstract}
Soils from Shorea javanica plantations in different parts of Lampung province, South Sumatra were sampled to a depth of $50 \mathrm{~cm}$ and described. They varied from quite deep loamy alkaline soils near Krui, to sticky acid clays behind Ngaras. The cation content of most samples was quite high, but organic nutrients were low, suggesting volcanic origin of the soils. Preliminary observations of performance in situ of 5 . javanica would suggest a requirement for deep loamy, fairly alkaline soils with a moderately high exchangeable cation content for optimal yield and performance.
\end{abstract}

\section{INTRODUCTION}

An important aspect in considering sites of $S$. javanica plantations is whether they can support a sufficiently productive tree crop. Resin is not always abundantly provided at all existing sites and this may be a function of environmental factors, such as soil, local climate or topography. This study is proposed to deal with soil characteristics suitable for $S$. javanica cultivation. Two approaches can be taken in the determination of the effect of soils on $S$. javanica performance. The first entails a survey of existing $S$. javanica stands, sampling the soils and gathering information on the health and resin productivity of the trees, and the second involves controlled growth experiments of seedlings on a range of soils, to estimate growth performance and thus select sites with soils yielding optimal production.

This report covers the first aspect, namely analysis of soils collected at various $S$. javanica sites in the Lampung Province of Sumatra.

\section{SITES}

1) Some time was spent in the region of Krui where resin production is good and villagers derive a reasonable income from its harvest. Soils have already been analysed from a site ca. $5 \mathrm{~km}$ from Krui (Torquebiau 1984), but as plantations are extensive within a radius of $30 \mathrm{~km}$ of the town, a second sample site was chosen at Palnam, $19 \mathrm{~km}$ from Krui on the Liwa road. About 3-400 m South of this road an outcrop of pink reef limestone was visible in a plantation and soil samples were taken from there.

* Present address: Department of Botany, University College, Go/way, Ireland. 
2) To the south of Krui, along the coast 'road' at Way Biha, a plantation was found in very sandy soil about 2-300 $\mathrm{m}$ from the beach. The trees, most of them ca. 20-30 years old were healthy and straight, ca. 20-30 m high, but resin production is poor, the bark thick, ca. 2-3 cm, and flower and fruit production occasional.

3) Further South, at Ngaras, S. javanica plantations extend up the hills at the back of the village. Near the village and halfway up the hill (site Ngaras I) soils were brown and fairly deep. Resin production is good on these lower slopes. Above these, at the top of the hill (site Ngaras II), soils were redder and more acidic. Resin production here is not so good. Further inland on higher slopes, soils were brown and less acidic, yet resin production was no better than at Ngaras II, indicating that caution should be used when correlating resin production and soil properties.

4) Two other sites were examined in Lampung, one at Wana, near Metro where a small stand of fairly old damar trees yielded soils of good crumb structure. The other, near Bakauheni was even smaller and probably disused for a longer time.

In each site, soils were sampled three times and subsampled at $5 \mathrm{~cm}$ and $30 \mathrm{~cm}$ depth. Methods for laboratory analyses were standard methods currently used in BIOTROP Tropical Forest Biology Program laboratory.

\section{RESULTS}

\section{Field soil descriptions}

These are summarized in Table 1 . The soils at Palnam indicate a fairly rapid litter decomposition and the resulting humus grades into the clayey substratum giving a fairly uniform brown color. At Ngaras, however, soils are only brown on the lower slopes (Ngaras I) and these overlay a stickier yellow-brown clay. On the upper slopes they were yellowish to yellow/orange throughout and more blocky in structure, with a thin litter/humus layer above. The soil at Way Biha was very sandy and poorly developed below $10 \mathrm{~cm}$, whereas at Wana and Bakauheni, soils had a good surface humic crumb structure, but beneath was reddish clay and a harsh smell of metal oxides (signs of temporary waterlogging?) was detectable.

\section{Laboratory analyses}

The range of texture (Fig. 1 and Table 2) relating to particle size is quite striking but if one considers only the soils where resin production is good (i.e. at Palnam and Ngaras I), these are loams with a fairly even proportion of each particle size class. Also among the loams are the samples from $5 \mathrm{~cm}$ depth at Wana and Bakauheni. However at $30 \mathrm{~cm}$, these contain very little sand and have a high proportion of clay. The Ngaras II soils are also low in sand content, whereas the coastal soils at Way Biha comprise little else.

The $\mathrm{pH}$ also shows a wide range, the most acid soils being those at Ngaras, especially Ngaras II. The others are not far from neutral ( $\mathrm{pH} 7)$. This relatively 
BIOTROPIA Vol. 1 No. 1, July-December 1987

Table 1. Summary of profile descriptions

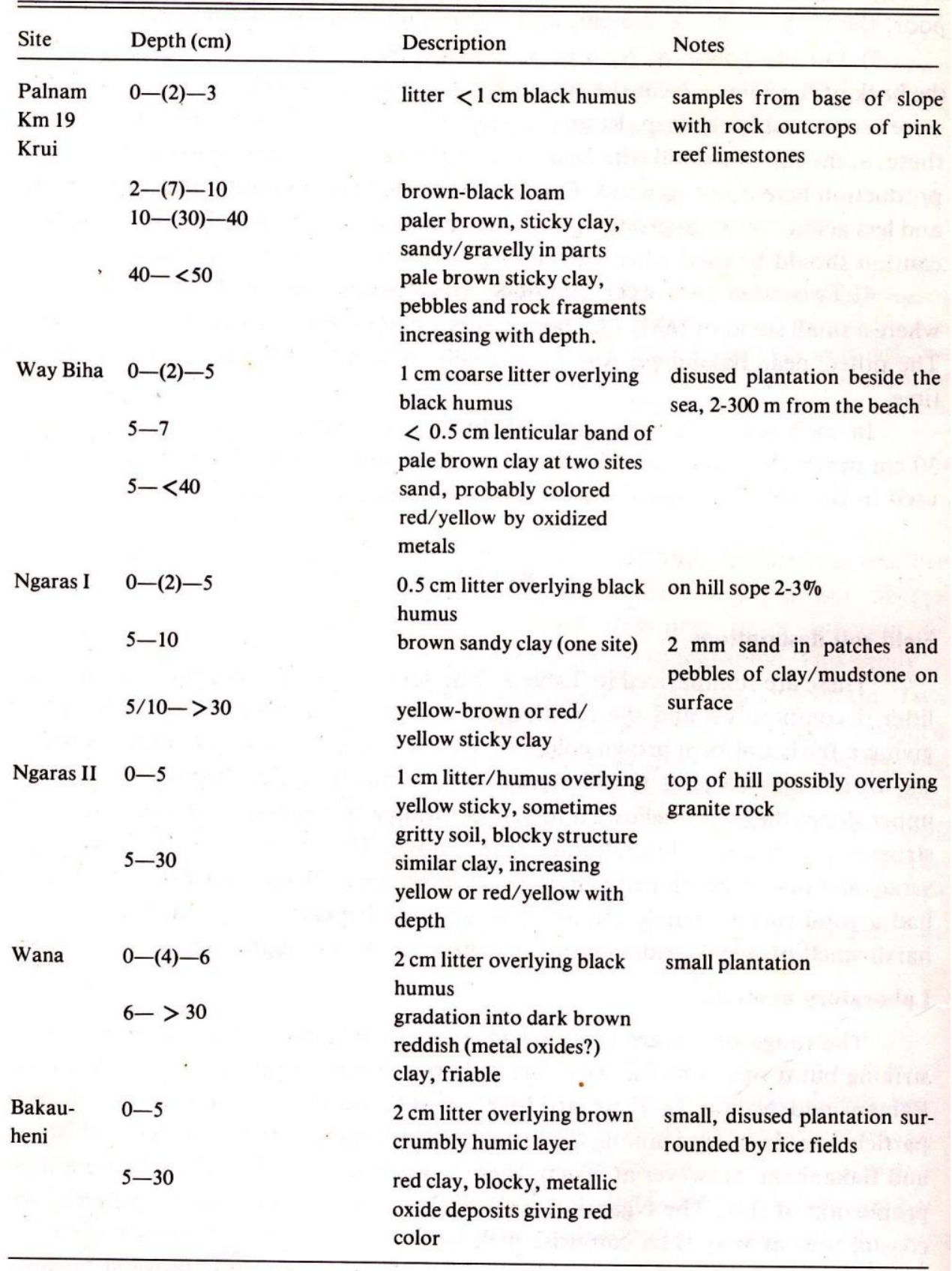


II. Soils from cultivated stands of Shorea javanica - Skeffington

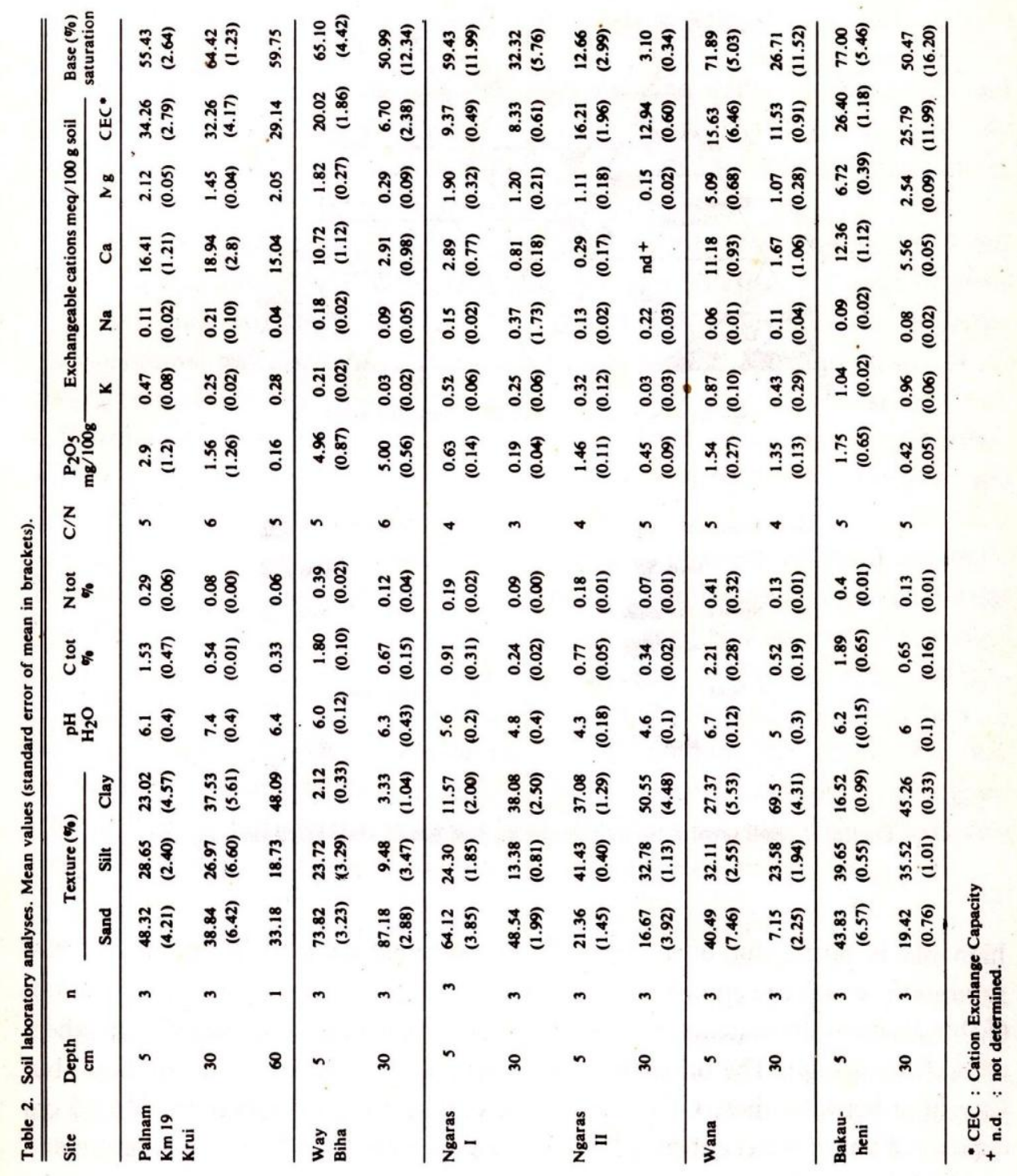



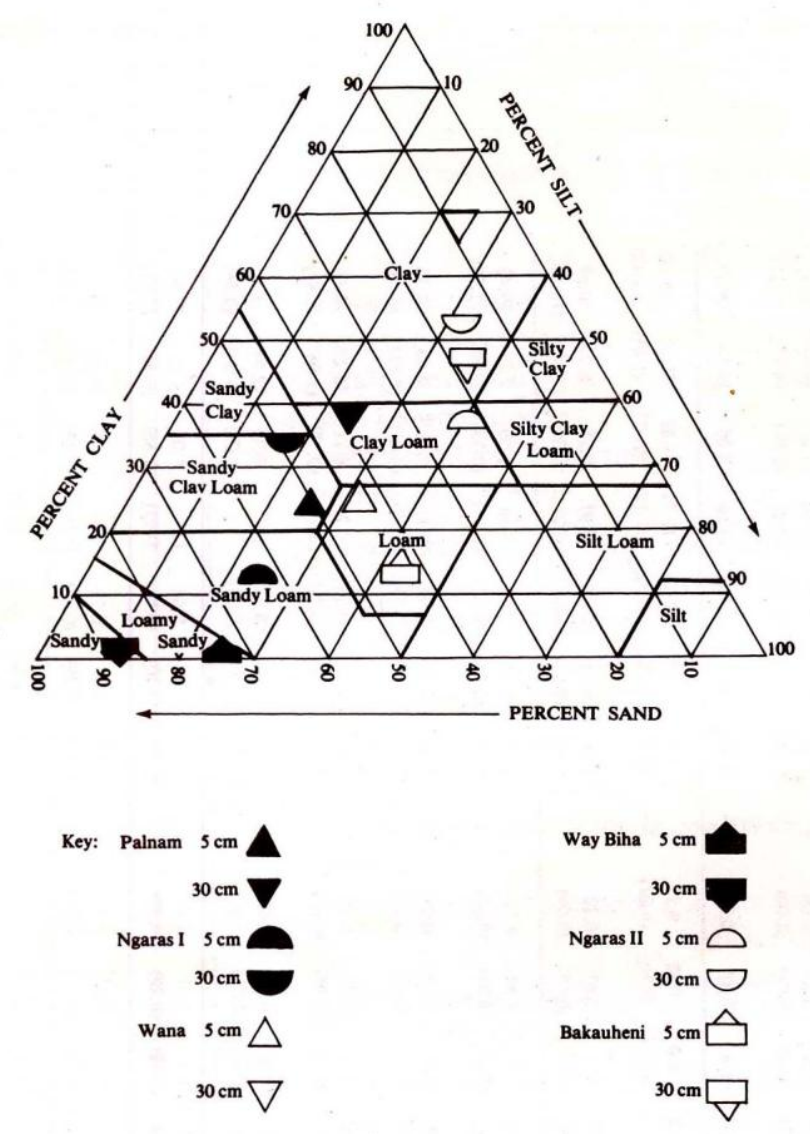

Figure 1. Soil texture triangle, showing position of soils listed on Table 2.

high $\mathrm{pH}$ is borne out by a high cation exchange capacity (C.E.C) and base saturation, which are comparatively low at Ngaras. Analysis of individual cations (Table 2) shows that calcium occupies most of the exchangeable sites in soils where the C.E.C. is high. The other three, especially $\mathrm{K}$ and $\mathrm{Mg}$ are relatively high, but vary little between sites. Of notable exception again are the samples from $5 \mathrm{~cm}$ depth at Wana and Bakauheni which both have a very high \% base saturation and also high $\mathrm{K}$ and $\mathrm{Mg}$ concentrations. The limestone bedrock must contribute to the high $\mathrm{pH}$ and calcium content of the Palnam soils. On the other hand, the organic constituents, total carbon and nitrogen, are very low for all soils, being lowest again at the Ngaras sites, which in this case differ little. The $\mathrm{C} / \mathrm{N}$ ratio is also low but this is indicative that $\mathrm{N}$ is being mineralized, suggesting rapid decomposition, 
and thus, low concentrations of these elements are not indicative of their probable rapid turnover. Inorganic phosphate is relatively low, being highest at Way Biha and Palnam. Accumulation of marine shells and detritus may be a high source of inorganic $\mathrm{P}$ at the coastal site of Way Biha.

\section{COMPARISON WITH OTHER SOILS}

Because of high rainfall, tropical soils generally rapidly become acidic and poor in bases due to fast weathering and leaching (Sanchez 1976). Only relatively recent alluvial or volcanic soils tend to be fertile and to a lesser extent those overlying exchangeable base-rich rocks such as limestone.

There is evidence that the Krui soils contain volcanic ash (Torquebiau 1964) and it is likely that those at Ngaras may also have received ash in the past. In terms of C.E.C. and exchangeable cations all soils compare favorably with fertile andosols developed on volcanic tuffs near Bogor in Java (Hardjosoesastro et al. 1983) where $\mathrm{Mg}, \mathrm{K}$ and especially $\mathrm{Ca}$ are in fact lower than in these soils. Other soils from Lampung have similar chemical properties (Adiningsih et al. 1983) including low carbon and nitrogen percentages, suggesting that the range of soil types presented here is relatively common in the province.

In general, the soils of Sumatra (and to a greater extent of Java), are more fertile than those of islands with little or no recent volcanic activity or large alluvial deposits. Islands such as Borneo have older, more weathered soils which are more acidic with a lower cation content and exchange capacity (Proctor et al. 1983).

Thus soils where $S$. javanica should grow relatively well would not be very acidic $(\mathrm{pH}>4.5)$, contain a moderate to high amount of cations, but not necessarily with high carbon, nitrogen or phosphate concentrations. For a good resin yield it may be important to select fairly deep base-rich soils which also have a good mix of sand, clay and silt resulting in a loamy texture.

\section{PROSPECTS FOR FUTURE RESEARCH}

The second part of the proposal outlined above, i.e. growth experiments, should follow directly from this preliminary investigation. For proper and vigorous growth of 5 . javanica seedlings, they would require to be grown in fertile base-rich soils of a good loamy texture. However, some estimate of their tolerance to less fertile soils can be derived from their experimental growth in a range of soils of different $\mathrm{pH}$ and fertility. Podzolic soils would have a $\mathrm{pH}$ similar to the more acid soils analyzed here and can be collected locally (e.g. at Jasinga). However, these may have moderately high concentrations of exchangeable cations (Adiningsih et al. 1983) and all soils thus used should be analyzed as described above to assess their comparability to the soils in the field. 
Performance of seedlings in poor soil conditions will probably be compounded by effects of over-shading or exposure to too much light (Bravo 1960). A two-way experiment to test the combined effects of range of soils (possibly adding fertilizer to some, Sundralingam 1983), and light conditions, would resolve optimal conditions for seedling growth as well as demonstrating which soil types are not conducive to healthy growth in either seedlings or adult trees.

Examples of more fertile soils which could be used locally are the andosols at Sukamantri described in Hardjosoesastroe et al. (1983). At Cisarua are some brown regosols, also volcanically-derived and fertile, which may prove to be the more suitable of the fertile soils.

Measurement of growth performance could include size, leaf number and $\mathrm{CO}_{2}$ uptake and subsequent harvest for biomass and nutrient content measurement.

\section{ACKNOWLEDGMENTS}

Thanks are due to Dr. Emmanuel Torquebiau for his help and advice as leader of the expedition. Also thanks to Mr. Ahmad Zainuddin for field assistance and Mr. Agus Nasir who carried out the laboratory analysis.

\section{REFERENCES}

ADININGSIH, J.S. and M. SUDJADI, 1983. The effect of submergence and fertilization on some characteristics of red yellow podsolic soils from central Lampung (in Indonesian). Pemberitaan Penelitian Tanah dan Pupuk No. 2. pp. 1-8.

BRAVO, P.R. 1980. Germination and initial growth of Shorea stenoptera and S. comoressa as affected by shading and different potting media. B1OTROP report on Training Course in Biological Aspects of Silviculture, Sept. 1979-July 1980, Bogor, Indonesia.

HARDJOSOES ASTRO, R., H. SUYANTOand A.M. SATARI. 1983. Andosol from the Sukamantri area of Bogor district (in Indonesian). Pemberitaan Penelitian Tanah dan Pupuk No. 2. pp. 18-29.

MARALI, M., O.K. HUSEIN and BACHRI, 1980. Hubungan sifat tanah podsolik dengan pertumbuhan tanaman tengkawang di Haurbentes, Jasinga, Bogor, Presiding No. 1, Penelitian Tanah, pp. 37-44.

PROCTOR, J., J.M. ANDERSON, S.C.L. FOODEN and H.W. VALLACK, 1983. Ecological Studies in four contrasting lowland rain forest in Gunung Mulu National Park, Sarawak. I Forest environment and floristics. Journal of Ecology, 71. pp. 237-260.

SANCHEZ, P.A. 1976. Properties and Management of Soil in the Tropics. Wiley, Chichester.

SUNDRALINGAM, P. 1983. Responses of seedlings of Dryobalanops aromatica and D. oblongifolia to commercial fertilizers. Malaysia Forester 46 (1) 86-92.

TORQUEBIAU,E. 1984. Man-made dipterocarp forest in Sumatra. Agroforestry Systems, 2. pp. 103-127. 